\title{
O ENSAIO SOBRE A LINGUAGEM EM GERAL E SOBRE A LINGUAGEM DOS HOMENS E OS PRESSUPOSTOS PARA UMA CONCEPÇÃO DE KRITIK BENJAMINIANA
}

Luciano Gomes Brazil

\begin{abstract}
RESUMO
O presente artigo se inicia com um estudo detalhado do ensaio de Walter Benjamin escrito em 1916, Sobre Linguagem em Geral e Sobre a Linguagem dos Homens, procurando encontrar os elementos para a Kritik benjaminiana tão característica em sua obra. A noção de Kritik em Benjamin carrega alguns pressupostos inerentes à sua Filosofia da Linguagem, quais sejam: uma linguagem que antes de ser instrumental é puro meio; uma concepção de linguagem que abarca a totalidade das coisas, isto é, não há como conceber aspectos ou partes da realidade fora da linguagem; e a supressão deste possível "fora" da linguagem pela noção de queda, oriunda da exegese do livro Gênesis. $E$ também a caracterização desta linguagem decaída como linguagem judicante: a linguagem que procura se compensar como juízo sobre algo. A segunda parte do artigo procura mostrar elementos da obra de Benjamin que se articulem tanto com os pressupostos trazidos de sua filosofia da linguagem quanto com uma possível relação direta da sua noção de crítica, tais como, por exemplo, a alegoria.
\end{abstract}

Palavras- chave: Linguagem. Benjamin. Crítica. Alegoria. Tradução.

\section{THE TEST ABOUT LANGUAGE IN GENERAL AND ABOUT MEN'S LANGUAGE AND THE ASSUMPTIONS FOR A CONCEPTION BY KRITIK BENJAMINIAN}

\begin{abstract}
The present article starts with a detailed study of the Walter Benjamin's essay written in 1916, On Language as Such and on the Language of Man, looking for the elements of the benjaminian's Kritik so characteristic in his work. The notion of Kritik in Benjamin carries some inherent assumptions oh his Philosophy of Language, namely: a language that before being instrumental, it is pure medium; a language conception that encompasses everything, videlicet, there is no way to conceive aspects or parts of reality out of language; and the suppression of that possible "out" of language for the notion of fall, from exegesis of the of Genesis. And also the characterization of this fallen language as a judging language, in other words, the language that seeks to compensate itself as a judgment about something. The second part of the article seeks to show elements of Benjamin's work that articulate as much the brought assumptions of his philosophy of language as a possible relation with his critics notion, such as, for example, the allegory.
\end{abstract}

Doutorando pelo PPGF - UFRJ. Brasileiro, residente no Rio de Janeiro-RJ. E-mail: brazil.filosofia@gmail.com 
Key-words: Language. Benjamin. Critic. Allegory. Translation

O texto a seguir é um estudo feito a partir daquele que talvez seja o mais conhecido ensaio de Benjamin sobre a linguagem, Sobre Linguagem em Geral e Sobre a Linguagem dos Homens, escrito em 1916, e que junto a outro, A Tarefa do Tradutor, escrito em 1921, perfazem em conjunto a filosofia da linguagem do referido autor. Neste estudo, pretendemos elencar alguns elementos que estão presentes nas noções de Crítica encontradas na obra de Walter Benjamin. Cabe ressaltar que embora a obra de Benjamin não seja homogênea, sofrendo uma série de transformações ao longo do percurso biográfico do autor, é possível, com o termo Crítica, salientar um sentido conceitual, que se reflete da abordagem sobre a linguagem realizados nestes ensaios de seus primeiros escritos.

O texto de 1916 começa dizendo que "toda manifestação da vida espiritual humana pode ser concebida como uma espécie de linguagem" (BENJAMIN, 2009, p.49). Tem-se aqui o que a nota da edição brasileira coloca da melhor maneira possível: na distinção entre Sprache e Rede vigora uma distinção binária, que no português fica melhor descrito a partir de uma distinção ternária: língua, linguagem e palavra, na medida em que Sprache pode ser traduzido por língua ou linguagem, e com isso também se possa falar de uma linguagem das coisas e dos animais, paralelamente à linguagem dos homens, o que estende a dimensão do sentido da linguagem:

toda comunicação de conteúdos espirituais é língua, linguagem, sendo a comunicação pela palavra apenas um caso particular (...) mas a existência da linguagem estende-se não apenas a todos os domínios de manifestação do espírito humano, ao qual, num sentido ou em outro, a língua sempre pertence, mas a absolutamente tudo. (BENJAMIN, 2009, 50)

Benjamin ao trazer a linguagem para a esfera total dá um passo definitivo em direção à concepção imediata, mágica e infinita da linguagem. Em direção a esta concepção, ele começa dizendo que não podemos "representar em parte alguma uma total ausência de linguagem" (BENJAMIN, 2009, 51), e que, ainda que a total ausência de linguagem pudesse ser uma ideia, ela seria uma ideia infecunda mesmo lá "no domínio daquelas ideias que definem, em seu âmbito, a ideia de Deus" (BENJAMIN, 2009, 51).

Doutorando pelo PPGF - UFRJ. Brasileiro, residente no Rio de Janeiro-RJ. E-mail: brazil.filosofia@gmail.com 
Ao diferenciar "essência espiritual" de "essência linguística", o autor apresenta o que ele próprio nomeia por paradoxo do logos. Faz-se importante o uso, com destaque textual, de advérbios e preposições: "O que comunica a língua? Ela comunica a essência espiritual que the corresponde. É fundamental saber que essa essência espiritual se comunica na língua e não através da língua" (BENJAMIN, 2009, 52).

É importante para Benjamin explicar em que medida não se identifica "essência espiritual" e "essência linguística" para se retirar o paradoxo de sua não solução, assim diz ele, no termo logos. A identidade entre ambas as essências ocorre na comunicabilidade. Benjamin diz que vistas "de fora", ambas não coincidem. Isto quer dizer o seguinte: a diferença entre o "na" ("em") língua e o "através da" língua se refere à incomunicabilidade da própria coisa, o que quer dizer que a coisa não se comunica senão o ser língua da coisa. Mas o ser língua da coisa é diferente da própria coisa, daí a distinção entre "essência linguística" e "essência espiritual", o que nos conduz à resposta à pergunta: "o que comunica a linguagem? (...) Toda linguagem comunica-se a si mesma", ou, duas linhas acima: "A linguagem comunica a essência linguística das coisas". (BENJAMIN, 2009, 53).

Essa comunicabilidade da própria linguagem é concebida como imediata. A essência linguística, aqui diferenciada de essência espiritual, é aquilo que se comunica a si mesma, e não através de si. Concebida como imediata, a essência linguística é a linguagem mesma, sem mediação.

Para deixar isto claro, Benjamin concebe a linguagem como Medium e distingue tal concepção da que a concebe como Mittel. Aquela é um meio em si mesma, que comunica a si própria, esta se concebe enquanto meio para fins. Páginas a frente o autor a chama de concepção burguesa, a dos meios de comunicação.

Benjamin entende que não é possível conceber a imediatidade da linguagem senão como mágica: "a imediatidade de toda comunicação espiritual é o problema fundamental da teoria da linguagem, e, se quisermos chamar de mágica essa imediatidade, então o problema originário da linguagem será sua magia". (BENJAMIN, 2009, 54) Sua magia traz outro aspecto, a infinitude:

Doutorando pelo PPGF - UFRJ. Brasileiro, residente no Rio de Janeiro-RJ. E-mail: brazil.filosofia@gmail.com 
"porque nada se comunica através da língua, aquilo que se comunica na língua não pode ser limitado nem medido do exterior, e por isso em cada língua reside sua incomensurável, e única em seu gênero, infinitude" (BENJAMIN, 2009, 54). Ora, medir do exterior a linguagem seria justamente delimitá-la e atribuir seu uso instrumental como meio para fins determinados.

Na sequência do texto, Benjamin passa da definição da linguagem em geral para a linguagem do homem: "A essência linguística das coisas é a sua linguagem; aplicada ao ser humano, essa afirmação significa que a essência linguística do ser humano é a sua língua" (BENJAMIN, 2009, 54). A comunicação do homem, na formulação de Benjamin a comunicação de sua essência espiritual, ocorre na língua. Observar que o autor diz que a essência linguística do homem é a sua língua, e não o contrário. Isto será importante quando nos detivermos quanto à pluralidade das línguas após a queda adâmica.

A peculiaridade do lugar do homem na totalidade da linguagem começa a ser traçada: "Mas a língua do homem fala em palavras. Portanto, o ser humano comunica sua própria essência espiritual (na medida em que ela seja comunicável) ao nomear todas as outras coisas" (BENJAMIN, 2009, 54). Aqui, um estranho problema: não poderíamos objetar que há algo estranho na linguagem dos homens frente à linguagem em geral, na medida em que 0 comunicar-se a si próprio do homem seja nomear todas as coisas? Por que haveríamos de conceber esse nomear como imediato, mágico e infinito? Qual a magia do nome?

Benjamin estava ciente destas questões, por isso ele formula as perguntas a seguir: "Para quê nomear? A quem se comunica o homem?" (BENJAMIN, 2009, 55) E na sequência, a distinção entre a essência linguística do homem e das coisas em geral, que é o que coloca o problema levantado acima: "Mas será essa questão, no caso do homem, diversa da de outras formas de comunicação (linguagens)?" (BENJAMIN, 2009, 55)

A distinção é a seguinte: após estabelecer que as coisas se comunicam na linguagem, que a "essência espiritual se comunica na língua", tornando-se claro que na comunicação da coisa o que se comunica ou expressa é o ser linguagem da coisa e não a própria coisa, parte-se da definição da linguagem do Doutorando pelo PPGF - UFRJ. Brasileiro, residente no Rio de Janeiro-RJ. E-mail: 
homem e concebe-se que no homem a língua fala em palavras e que, portanto, o homem comunica sua essência linguística ao nomear as coisas. Da linguagem em geral à linguagem dos homens descobrimos o nome, o ato de nomear, ligado à essência linguística deste, distintamente da linguagem em geral. Isto para Benjamin é por demais importante: "ao identificar linguagem nomeadora e linguagem em geral, a teoria da linguagem acaba por privar-se de suas percepções mais profundas" (BENJAMIN, 2009, 54-55, grifo nosso).

A nomeação, o ato nomeador, ocorre a partir da magia da linguagem. Isto não quer dizer outra coisa senão que tal ato e o próprio nome não são arbitrários, mas sim essenciais. Por isso ele pergunta na sequência: "A quem se comunica a lâmpada? A quem, a montanha? E a raposa? - Aqui a resposta: ao homem. Não se trata de antropomorfismo. A verdade dessa resposta se deixa ver no conhecimento e, talvez, na arte" (BENJAMIN, 2009, 55).

Admitindo esta concepção da linguagem, temos que a nomeação e o ato de nomear são complementos da criação: uma vez criadas as coisas, resta darIhes nomes. Papel esse atribuído por Deus a Adão: "Se a lâmpada e a montanha e a raposa não se comunicassem ao homem, como poderia ele nomeá-las? No entanto, ele as nomeia; ele se comunica ao nomeá-las. A quem ele se comunica? (BENJAMIN, 2009, 55).

Após rapidamente apresentar a alternativa rejeitada ${ }^{1}$, o autor expressa taxativamente: "no nome a essência espiritual do homem se comunica a Deus" (BENJAMIN, 2009, 55). Com essa definição, Benjamin fecha toda a questão da linguagem. A partir daí ele começa a pôr a amplitude da definição, antes de passar à descrição da queda. É o que tentaremos reproduzir na sequência.

Atribui-se ao nome a essência mais íntima da língua. De maneira negativa isto quer dizer que nada mais se comunica através do nome; e de maneira positiva isto quer dizer que o nome é aquilo em que a "própria língua se comunica

1 Como dissemos acima, a alternativa apresentada é a concepção burguesa da linguagem. A que concebe a linguagem como aquilo que o homem comunica sua essência através dos nomes. Tal concepção não consegue explicar por que a linguagem comunica a essência espiritual do homem, na medida em que essa concepção se limita à comunicação de algo, que não o homem, a outro homem: "Essa visão afirma que o meio da comunicação é a palavra; seu objeto, a coisa; seu destinatário, um ser humano. Já a outra concepção não conhece nem meio, nem objeto, nem destinatário da comunicação" (BENJAMIN, 2009, $55)$.

Doutorando pelo PPGF - UFRJ. Brasileiro, residente no Rio de Janeiro-RJ. E-mail: brazil.filosofia@gmail.com 
a si mesma, e de modo absoluto"2 (BENJAMIN, 2009, 56), posto que se fosse de modo relativo, se daria possibilidade de se compreender a língua como meio (Mittel) para fins externos a ela. Em seguida, Benjamin completa: "como parte do legado da linguagem humana, o nome garante que a língua é pura e simplesmente a essência espiritual do homem; e é somente por isso que o homem é, entre todos os seres dotados de espírito, o único cuja essência espiritual é plenamente comunicável" (BENJAMIN, 2009, 56, grifo dele).

Temos duas observações importantes aqui: no início do texto, Benjamin tomando deliberadamente um ponto de vista externo distinguiu essência espiritual e essência linguística. No trecho acima, nosso autor coincide ambas as essências, com relação ao homem, e na sequência do texto, como veremos a seguir, com relação a todas as coisas e à linguagem em geral; a segunda observação é a de que somente no homem, dentre os seres dotados de espírito, a essência espiritual é "plenamente comunicável". Podemos chamar de teoria do nome este e outros trechos em que se coloca a questão do nome na sua relação com a coisa criada. Se a língua é a essência espiritual do homem, conclui-se que ele se comunique somente nela, na língua, e não através dela. De tal maneira que "o nome é a condensação dessa totalidade intensiva da língua como essência espiritual do homem" (BENJAMIN, 2009, 56).

Quem é, portanto, o homem? O homem é aquele que nomeia, aquele que "por sua boca fala a pura língua" (BENJAMIN, 2009, 56). Podemos afirmar que se não é o homem que fala através da linguagem, é a linguagem que fala através do homem? E neste sentido afirmar que tendo a linguagem fim em si mesma, seu meio seria esse homem que nomeia? Segundo a resolução de Benjamin, não. Por dois motivos: o primeiro deles é a concepção de natureza que o autor nos oferece no texto; o segundo é a formulação do genitivo "língua

2 À parte a presença do judaísmo na concepção da linguagem, Benjamin se insere em uma antiga discussão da filosofia da linguagem. A base desta discussão remete à filosofia ática, do embate entre Sócrates e os sofistas, transmitidos nos diálogos de Platão. E é no diálogo Crátilo onde testemunhamos a mesma polêmica de Benjamin entre dois tipos, ou duas concepções, de linguagem. Trata-se da polêmica entre Hermógenes e Crátilo, a qual Sócrates intervém a fim de encontrar a solução. Neste debate, a concepção benjaminiana se identifica com a posição de Crátilo ante a de Hermógenes, para quem a relação entre palavras e coisas era arbitrária. Cf. PLATÃO, Crátilo. Tradução de Carlos Alberto Nunes. Belém: editora Universidade Federal do Pará, 1988 
da língua" ou "linguagem da linguagem". Benjamin diz: "Toda natureza, desde que se comunica, se comunica na língua, portanto, em última instância, no homem" (BENJAMIN, 2009, 56). A natureza se comunica no e não através do homem; é igualmente possível que, na linguagem decaída (como veremos na sequência) a natureza mude de caráter, porque, afinal, a linguagem que fala no homem não é mais a mesma após a queda.

A segunda objeção ao problema colocado aparece plenamente na seguinte frase: "porque ele fala no nome, o homem é o falante da linguagem" (BENJAMIN, 2009, 56). No fundo, esta é uma variação da formulação anterior que dizia que a língua é a essência espiritual do homem, em cuja comunicação plena está o nome, "língua da língua" ou "linguagem da linguagem", e entre parênteses uma afirmação de não menos importância: "desde que o genitivo não designe uma relação de 'meio' [Mittel], mas de meio [Medium]. Portanto, nem a linguagem que fala no homem, nem ele mesmo, podem ser compreendidos como meio para fins. Se o homem fosse concebido como Mittel, também a linguagem o seria.

E assim, completando o itinerário desta teoria da linguagem adâmica, Benjamin concebe o nome ${ }^{3}$ como "verdadeira interpelação da linguagem", no qual "expressar-se a si mesmo e interpelar todas as outras coisas são um só movimento" (BENJAMIN, 2009, 57). Diz Benjamin que essa é "a lei universal da linguagem", e oferece duas direções para esta definição: a "totalidade intensiva da língua", e a "totalidade extensiva da língua" (BENJAMIN, 2009, 57). Para a primeira direção ele a atribui a "essência absolutamente comunicável", e para a segunda direção, como "essência absolutamente comunicante (que nomeia)" (BENJAMIN, 2009, 57) E, em seguida, completa: "A linguagem será imperfeita em sua essência comunicante, em sua universalidade, quando a essência espiritual, que fala a partir dela, não for, em toda sua estrutura, algo linguístico, isto é, algo comunicável" (BENJAMIN, 2009, 57). Aqui ele retoma algo que fora rapidamente expresso logo no início do ensaio: "Não há evento ou coisa, tanto

3 O chamar do nome é onde reside a comunicação.

Doutorando pelo PPGF - UFRJ. Brasileiro, residente no Rio de Janeiro-RJ. E-mail: brazil.filosofia@gmail.com 
na natureza animada, quanto na inanimada, que não tenha, de alguma maneira, participação na linguagem" (BENJAMIN, 2009, 51). Mas se lá, naquele trecho, preparando o percurso, Benjamin estabeleceu a distinção entre essência espiritual e essência linguística, aqui o autor completa o círculo e estende a identificação entre essência espiritual e linguística não mais apenas ao homem, mas a todas as coisas:

Trata-se de saber se, do ponto de vista de uma teoria da linguagem, deve-se definir toda essência espiritual como linguística - não apenas a do ser humano (pois no seu caso isso se dá necessariamente), mas também a essência das coisas e, com isso, toda e qualquer essência espiritual em geral. Se a essência espiritual for idêntica à essência linguística, a coisa é, em sua essência espiritual, o meio da comunicação, e aquilo que nela se comunica é - em função desse estatuto de meio - precisamente esse próprio meio (a linguagem). Assim, a linguagem é a essência espiritual das coisas. (BENJAMIN, 2009, 57-58)

Escolhemos esta longa citação para mostramos a virada que Benjamin realizou. Se no início do ensaio era preciso manter separadas essência linguística de essência espiritual, agora nosso autor demonstra que a comunicabilidade da coisa não pode ser separada da própria coisa. Em sua sequência, Benjamin faz outra importante conclusão:

A essência espiritual, portanto, é colocada desde o princípio como comunicável, ou melhor, colocada justamente na comunicabilidade, e a tese segundo a qual a essência linguística das coisas é idêntica a sua essência espiritual, enquanto esta é comunicável, torna-se com este "enquanto" uma tautologia. Não há um conteúdo da língua, ou da linguagem; enquanto comunicação a linguagem comunica uma essência espiritual, isto é, uma comunicabilidade pura e simples. (BENJAMIN, 2009, 58, grifo do autor) ${ }^{4}$

A sequência do ensaio sobre a linguagem, contudo, ainda possui mais elementos do que os apresentados aqui, em particular a queda. Mas ainda antes

\footnotetext{
4 Em uma carta a M. Buber (1878-1965), descrevendo o ensaio em questão, diz nosso autor: "somente onde essa esfera do que não tem palavra se abre em poder puro e indizível pode saltar a faísca mágica entre a palavra e o ato motivador, onde há unidade desses dois que são igualmente reais". (BENJAMIN apud WITTE, 2017, 34). Comentando tanto a teoria da linguagem quanto o trecho da carta supracitada, Witte nos diz algo que nos é importante: a relação central que a linguagem possui nos desdobramentos da obra de Benjamin. Witte a relaciona diretamente com diversos eventos da vida do autor, como a morte de seu amigo e poeta Cristoph F. Heinle (1894-1914), a experiência da guerra, e o fracasso do movimento juvenil. Diz Witte: "O tema de tais esforços no limite do silêncio é a salvação de experiências que não são disponíveis ao conhecimento racional. A unidade dos diferentes projetos de uma teoria autônoma, nascidos do fracasso do movimento juvenil, deve ser pensada como síntese de filosofia da história, crítica literária e teoria da linguagem, na qual sempre 'a linguagem é pressuposta como uma realidade última, inexplicável e mística, contemplável apenas em seu desdobramento". (WITTE, 2017, 34)
}

Doutorando pelo PPGF - UFRJ. Brasileiro, residente no Rio de Janeiro-RJ. E-mail: brazil.filosofia@gmail.com 
dela, não podemos nos esquecer que Benjamin traz um elemento central desta questão da linguagem: a revelação. Partindo de uma equiparação entre essência linguística e espiritual, estabelece-se uma "gradação de todo ser espiritual" (BENJAMIN, 2009, 58). Todas as coisas estão na linguagem, em maior ou menor grau, e de acordo com o nível espiritual da própria coisa. O que é importante dessa gradação é a conclusão de que não há um ponto externo para falar de coisas espirituais. Esse caráter imanente da linguagem é bastante característico da concepção de Benjamin. A linguagem nunca fala desde uma perspectiva externa, caso contrário ela não comunica. Esta é a condição de sua comunicabilidade, e também sua magia. Ela não tem nada a dizer senão a si própria. Nosso autor salienta que o tão grande alcance metafísico da teoria da linguagem se deve ao conceito de revelação. Mas devemos ficar atentos ao fato que Benjamin na sequência contesta a concepção da linguagem que estabelece uma relação inversamente proporcional entre o espiritual e o linguístico. Para nosso autor, a relação entre espírito e linguagem é "absolutamente unívoca": "a tese aqui é de que quanto mais profundo, isto é, quanto mais existente e real for o espírito, tanto mais exprimível e expresso" (BENJAMIN, 2009, 59). Com isso, a revelação não se confunde com o inexprimível, ela é o seu limite, "pois este (o inexprimível) é convocado no nome e se diz como revelação". Benjamin, inclusive, chega a estabelecer uma hierarquia, a partir do caráter da revelação, com as artes, em específico a poesia:

o que assim se anuncia é que só a essência espiritual mais elevada, tal como ela se manifesta na religião, repousa puramente sobre o homem e sobre a linguagem no homem, ao passo que toda arte, inclusive a poesia, não repousa sobre a quintessência do espírito da linguagem, mas repousa sobre o espírito linguístico das coisas, ainda que em sua perfeita beleza (BENJAMIN, 2009, 59)

Há um aspecto particularmente significativo na exegese benjaminiana do Gênesis que observa a relação entre as palavras e as coisas e a cognoscibilidade destas, primeiramente do ponto de vista do criador e depois do ponto de vista do homem. Deve-se notar "a profunda e clara relação do ato criador com a linguagem" (BENJAMIN, 2009, 61). Primeiro a relação é a da "onipotência criadora da linguagem" e depois (neste trecho do texto o autor diz 
"ao final", mas não deixa claro o que quer dizer com isso, aparentemente ele fala da linguagem no homem) "a linguagem incorpora a si o criado, ela o nomeia" (BENJAMIN, 2009, 61).

A linguagem é ao mesmo tempo "palavra e nome", criação e conhecimento; "em Deus o nome é criador por ser palavra, e a palavra de Deus é saber por ser nome" (BENJAMIN, 2009, 61). Com isso, Benjamin afirma: "a relação absoluta do nome com o conhecimento só existe em Deus" (BENJAMIN, 2009, 61). É o absoluto puro meio do conhecimento. Deus conhece as coisas porque as criou ao lhes dar nomes; no homem a relação é inversa: ele as nomeia à medida que as conhece.

O lugar e o papel do homem são colocados pelo seu lugar perante Deus e perante as demais coisas criadas. Estas se comunicam em sua imediatidade material, porém são mudas. Benjamin não está dizendo que elas não sejam mágicas, infinitas e imediatas, que são as três principais características da linguagem, conforme vimos acima. Ele só está afirmando que a elas é "negado o puro princípio formal da linguagem que é o som" (BENJAMIN, 2009, 60). A comunicação das coisas é da ordem de uma comunidade material, embora aparentemente e conforme as denominações anteriores, estas sejam "essências espirituais". Outra observação que devemos aqui subscrever, é que o autor não estabelece explicitamente se ao falar de coisas ele faz uma distinção com os animais. Isto fica algo implícito ao dizer que há gradações entre as coisas criadas, e o lugar do homem entre elas, daí a afirmação: "Somente o homem possui a linguagem perfeita do ponto de vista da universalidade e da intensidade" (BENJAMIN, 2009, 57, sem o grifo dado pelo autor), ou seja, no homem só se fala em perfeição da linguagem na medida em que a ele é dado o poder de nomear as coisas. Ao homem foi dado o dom, se é que assim podemos dizer, puramente espiritual: "O que é incomparável na linguagem humana é que sua comunidade mágica com as coisas é imaterial e puramente espiritual, e disso o símbolo é o som" (BENJAMIN, 2009, 60).

Este som, figurado na imagem bíblica do sopro de Deus, diz Benjamin, é ao mesmo tempo "vida, espírito e linguagem" (BENJAMIN, 2009, 60). Esta singularidade do homem no ato divino da criação é também, como não poderia Doutorando pelo PPGF - UFRJ. Brasileiro, residente no Rio de Janeiro-RJ. E-mail: 
ser diferente, a singularidade da linguagem do homem. Não só, como aludimos acima, pela relação entre conhecimento e nome, mas porque a criação do homem não o foi pelo nome, o que quer dizer que Deus não o nomeou, não o "submeteu à linguagem", mas o liberou para ela. Por que a linguagem é puro meio? Porque o ato de nomear realizado por Deus é ao mesmo tempo ato criador. À parte da criação, o homem ao nomear a si próprio e as coisas está em comunicação com Deus pela palavra: "Sua [a do homem] essência espiritual é a linguagem em que ocorreu a criação" (BENJAMIN, 2009, 62).

Que toda linguagem humana seja o reflexo da palavra de Deus, no entanto, não aproxima o homem da essência criadora de Deus: "A infinitude de toda linguagem humana permanece sempre de maneira limitada e analítica em comparação com a infinitude absoluta, ilimitada e criadora da palavra divina (BENJAMIN, 2009, 62).

Antes de definir a linguagem humana como tradução, Benjamin parece encerrar a teoria do nome, que havia iniciado páginas antes, agora vertida em nome próprio: "O nome próprio é o que o homem tem em comum com a palavra criadora de Deus" (BENJAMIN, 2009, 63). Além de oferecer mais uma refutação ao que ele chama de concepção burguesa da linguagem, que atribui uma arbitrariedade na relação entre palavras e coisas, "a linguagem não fornece jamais meros signos" (BENJAMIN, 2009, 63), Benjamin refuta também a "teoria mística" que defende que a "palavra é a essência da coisa" (BENJAMIN, 2009, 63). Se por outro lado, Benjamin rejeita a atribuição arbitrária entre palavras e coisas, ele não pode conceber que esteja na palavra a essência das coisas, pois o homem não participa do ato criador senão pela comunicação da coisa, que fora criada por Deus:

a coisa enquanto tal não tem nenhuma palavra; criada a partir da palavra de Deus, ela é conhecida em seu nome pela palavra do homem. Esse conhecimento da coisa não é, contudo, uma criação espontânea, ele não acontece a partir da linguagem de maneira absolutamente ilimitada e infinita, como ocorre na criação; o nome que o homem atribui à coisa repousa sobre a maneira como ela se comunica a ele ${ }^{5}$. (BENJAMIN, 2009, 64-65)

5 Na sequência do trecho citado, Benjamin conclui: "No nome a palavra divina não continua criadora; ela se torna em parte uma receptividade ativa, uma receptividade que concebe, ainda que tal concepção seja de linguagem. Essa receptividade responde à linguagem das coisas mesmas, das quais, por sua vez, a Doutorando pelo PPGF - UFRJ. Brasileiro, residente no Rio de Janeiro-RJ. E-mail: 
Benjamin escreveu anos depois um ensaio sobre tradução. Em parte seu itinerário já está prefigurado nesta concepção de linguagem. Que a linguagem dos homens seja a tradução nomeadora das coisas enquanto criadas, a "tradução da linguagem das coisas para a linguagem do homem" (BENJAMIN, 2009, 64).

Há uma dificuldade no interior desta concepção de Benjamin que poderia nos levar a confundir a sua definição de linguagem. A descrição da criação dizia que ela ocorreu na palavra e ao homem, criado não pela palavra, mas à imagem e semelhança, Ihe ocorreu não como submetendo-o, mas liberando-o à palavra. A diferença entre $o$ ato criador do homem e $o$ ato criador das coisas determina a tarefa do homem enquanto tradução. Certamente as coisas são criadas na palavra, e, por isso, elas são puro meio, mas sua essência espiritual é outra que a do homem (na verdade, esta é a dificuldade, apresentada linhas acima). Em última instância, e segundo as denominações do autor, estas essências nem espirituais são, ou são espirituais em graus menores: elas são materiais. Ao homem, essência espiritual diversa e, além disto, criatura e não criador, cabe o papel de verter em nomes as coisas, a partir das coisas. Com tal concepção, Benjamin pretende alavancar a noção de tradução, para que se possa fundamentar "no nível mais profundo da teoria linguística, pois ele [o conceito de tradução] possui alcance e poder demasiado amplos para ser tratado de uma maneira qualquer" (BENJAMIN, 2009, 64).

Ainda no mesmo parágrafo, o autor berlinense define a tradução como relação entre línguas cujos meios possuem densidades diferentes: "a tradução é a passagem de uma língua para outra por uma série contínua de metamorfoses" (BENJAMIN, 2009, 64), em vez de "regiões abstratas de igualdade e similitude" (BENJAMIN, 2009, 64). No parágrafo seguinte, ele salienta que traduzir da linguagem das coisas para a linguagem dos homens não

palavra divina se irradia, sem som, na magia muda da natureza" (BENJAMIN, 2009, 64). Somente a partir desta noção de receptividade ativa é que se pode compreender a noção de tradução, pois afinal, certamente ninguém concebe que traduções sejam arbitrárias. A linguagem humana do nome seria, profundamente, uma tradução da linguagem material das coisas.

Doutorando pelo PPGF - UFRJ. Brasileiro, residente no Rio de Janeiro-RJ. E-mail: brazil.filosofia@gmail.com 
é apenas fazer a passagem do mudo para o sonoro, e sim "traduzir aquilo que não tem nome em nome". (BENJAMIN, 2009, 64)

Benjamin aproxima a tarefa do conhecimento à tarefa da tradução pela função nomeadora do homem. O estranho é que ele parece atribuir a Deus uma nomeação, mas o nome dado por Deus não é o mesmo dado pelo homem. A citação a seguir percorre esse problema: "Deus criou as coisas e nelas a palavra criadora é o gérmen do nome que conhece, da mesma forma como Deus também, ao final, nomeava cada coisa após tê-la criado" (BENJAMIN, 2009, 65). Tudo nos leva a crer que em Deus nome e palavra criadora são absolutamente próximos, senão o mesmo ("palavra criadora é o gérmen do nome que conhece"), embora cada uma esteja implicada com um ato distinto: a palavra à criação; o nome a, após a criação, o chamado, e porque Deus chama pelo nome, ele conhece a coisa nomeada. O autor prossegue: "essa nomeação constitui somente a expressão da identidade, em Deus, entre a palavra criadora e o nome que conhece, e não a solução antecipada para aquela tarefa que Deus atribui expressamente ao próprio homem: nomear as coisas" (BENJAMIN, 2009, 65). Resta saber então se esse nome dado pelo homem coincide com o nome dado por Deus. Não é difícil deduzir que não, eles não coincidem. Já aludimos a isto acima, na contestação de Benjamin à teoria mística que associa essência e palavra. "Recebendo a língua muda e sem nome das coisas e transpondo-as em sons, nos nomes, o homem solve esta tarefa" (BENJAMIN, 2009, 65). E na sequência, aquilo que aqui concebemos como a posição peculiar de Benjamin quanto à linguagem. Ele diz:

\footnotetext{
Mas esta tarefa seria insolúvel se a língua nomeadora do homem e a língua sem nome das coisas não tivessem uma proximidade de parentesco em Deus, oriundas da mesma palavra criadora, tornada, nas coisas, comunicação da matéria em uma comunidade mágica, e, no homem, linguagem do conhecimento e do nome em um espírito bem-aventurado. (BENJAMIN, 2009, 65)
}

Nesta altura, Benjamin encerra a concepção mística e paradisíaca da linguagem. A partir daí Benjamin descreve a queda, Südenfall, do homem. Cabe, portanto, fazermos um apanhado do que lemos até aqui. Temos, assim, o seguinte estado de coisas: Benjamin está lendo o Gênesis junto com autores 
místicos. Nominalmente ele cita Hammann ${ }^{6}$ (1730-1788), e os místicos que ele refuta, não chega a nomear. Nessa leitura, cabe a Benjamin afastar as concepções que instrumentalizam a linguagem, atribuindo-a uma relação de meios para fins externos a ela, e também uma relação de arbitrariedade de signos. Mas ainda que tendo um ponto de partida teísta, nosso autor é cuidadoso na atribuição dada ao homem com relação às coisas, pois, se de um lado não é o homem um designador arbitrário de nomes, ao menos o nome dentro do estado paradisíaco, de outro ele não tem o poder de, no ato de nomear, essencializar a coisa pela palavra. Nos dois extremos redunda-se uma arbitrariedade, de um lado a de uma onipotência criadora que ele não possui; e de outro, uma arbitrariedade impossível na medida em que a coisa e o nome estão em comunidade imediata, oriundas da criação.

É de nosso interesse agora acompanhar o texto de Benjamin em sua parte final, aquela justamente em que ele descreve a queda. Essa concepção traz o outro lado da teoria da linguagem de Benjamin, e acompanha quase todas as leituras feitas sobre o autor no tocante a este tema.

Dentre as coisas da criação dispostas para o homem, uma delas não possui nome, é o "saber sobre o que é bom e o que é mau" (BENJAMIN, 2009, 67). Essa ausência do nome aqui não é arbitrária. Tal ausência, diz o autor, é um saber nulo, a sua condição é retirar o nome do nome: "O saber sobre o que é bom e o que é mau não tem a ver com o nome, é um conhecimento exterior" (BENJAMIN, 2009, 67). Parece ser a condição para todo juízo o caráter transcendente, isto é, o juízo fala, ou pretende falar, a partir de algo que está fora de si próprio. Esta é a sua condição. Ele é, portanto, a condição inversa da linguagem paradisíaca. Linhas acima havíamos mencionado o caráter imanente da linguagem paradisíaca; após a queda a linguagem possui um caráter transcendente, o juízo na linguagem a partir da condição não paradisíaca necessariamente adota uma perspectiva externa a si própria:

6 Johan Georg Hammann, que viveu no auge do racionalismo iluminista do século XVIII, foi um dos primeiros a criticar Kant e a refutar o criticismo do filósofo de Königsberg. Sua refutação a Kant é importante influência para W. Benjamin.

Doutorando pelo PPGF - UFRJ. Brasileiro, residente no Rio de Janeiro-RJ. E-mail: brazil.filosofia@gmail.com 


\begin{abstract}
Nesse conhecimento, o nome sai de si mesmo: o pecado original é a hora de nascimento da palavra humana, aquela em que o nome não vivia mais intacto, aquela palavra que abandonou a língua que nomeia, a língua que conhece, pode-se dizer: abandonou a sua própria magia imanente para reivindicar expressamente seu caráter mágico, de certo modo, a partir do exterior. (BENJAMIN, 2009, 67)
\end{abstract}

Temos nessa altura, na descrição de Benjamin da saída do homem da condição paradisíaca, a separação definitiva entre palavra e nome. Por isso Benjamin só chama de "palavra humana" esta posterior a queda, a palavra que não mais comunica a partir do nome. Para completar o sentido desta palavra que não comunica a partir do nome, ela a descreve como aquela linguagem que reivindica a comunicação desde a exterioridade do nome. Ela reivindica o caráter mágico desde uma perspectiva externa, o que, de todo modo, contraria a própria magia da linguagem. $O$ pecado original deflagra que a palavra deva comunicar algo que não a si própria.

Segundo a Bíblia, o que motivou o pecado foi a promessa de um conhecimento sobre o bem e o mal. Há uma "identidade fundamental" entre "a palavra que conhece o bem e o mal" e a palavra que comunica desde o exterior. Uma vez distintos palavra e nome, tal conhecimento sobre o bem e o mal não se confunde com o conhecimento das coisas. A citação que Benjamin faz de Kierkgaard não é fortuita. O filósofo dinamarquês chama de "tagarelice" esta comunicação pós queda.

Esta "tagarelice", diz Benjamin, só poderia chegar a uma "purificação" e a uma "elevação" através do tribunal. A palavra pós queda, tagarela, só poderia reencontrar-se consigo mesma no tribunal. Não nos esqueçamos, é porque queremos tornar patente a noção de crítica na obra de Benjamin que estamos aqui esmiuçando o sentido de linguagem na obra de nosso autor.

Com a queda, a palavra perde seu caráter imediato e torna-se mediada, meio para fins externos a si própria. Agora a palavra é um signo, ela assinala alguma coisa, sem que seja a própria coisa; agora a palavra é representação e correspondência com o objeto. Não sendo a palavra de Deus, ela não pode julgar sem que entregue ao homem a culpa. Por isso ela é decaída, e também é por isso que ela agora busca "elevação" e "purificação". A palavra que julga está entregue a uma lei inexorável:

Doutorando pelo PPGF - UFRJ. Brasileiro, residente no Rio de Janeiro-RJ. E-mail: brazil.filosofia@gmail.com 
Essa palavra que julga expulsa os primeiros homens do paraíso; eles mesmos a incitaram, em conformidade com uma lei eterna segundo a qual essa palavra que julga pune seu próprio despertar como a única, a mais profunda culpa - e é isso que ela espera (BENJAMIN, 2009, 67).

Benjamin estabelece uma tríplice significação entre linguagem e pecado original: (1) a transformação da linguagem em meio (Mittel), e por consequência a transformação dela em mero signo, relação direta com a pluralidade de línguas; (2) a nova imediatidade, em lugar da magia do nome, a magia do julgamento "que não mais repousa feliz em si mesma" (BENJAMIN, 2009, 68); (3) e Benjamin se arrisca em supor um terceiro significado, a da origem da abstração na linguagem. A tese de Benjamin para esta hipótese é bastante coerente segundo o percurso que ele empreendeu: a tese de que o conhecimento do bem e do mal remanescem sem nome. A ausência do nome indica a ausência de um objeto concreto, de um objeto no fenômeno, enquanto coisa criada: "o nome fornece apenas o solo no qual seus elementos concretos se enraízam" (BENJAMIN, 2009, 68). É porque o conhecimento do bem e do mal depende de um juízo de valor e a este não se pode atribuir um objeto.

A imediatidade após a queda é a do "veredicto judicial". Mas ela se dá junto ao "abismo do caráter mediado de toda comunicação" (BENJAMIN, 2009, 69). Em lugar da imediatidade do nome, a mediatidade da comunicação. A imediatidade judicante é "pura tagarelice". Não é difícil supor que a imediatidade judicante só seria possível se ela pudesse dar conta da totalidade desde o ponto de vista divino. Mas como ela não participou da criação, ela não possui condições de chamar as coisas pelo nome, e com isso ela será sempre uma tagarelice: "A palavra que comunica do exterior, expressamente mediada, é de certa forma uma paródia da palavra imediata, da palavra criadora de Deus" (BENJAMIN, 2009, 67). Mas Benjamin ainda enfatiza outro caráter a este segundo sentido de linguagem: uma vez vinculada ao juízo, ao julgamento, sua "insígnia" foi justamente ela ter recaído por sobre "aquele que pergunta", e Benjamin ainda completa: "Essa monstruosa ironia é o sinal distintivo da origem mítica do direito" (BENJAMIN, 2009, 69, grifo nosso).

Passando pela explicação da pluralidade de linguagens, fazendo alusão à torre de Babel, e da confusão entre as línguas, na sequência, Benjamin 
estabelece a relação entre linguagem e natureza. Antes da queda a mudez era beatitude (certamente por conta da inocência do homem), após a queda a mudez é sinônimo de tristeza. Já se insinua aí um tema que é importante para o autor berlinense em sua teoria estética e sua filosofia da história: a melancolia e o luto: "Em todo luto, há uma profunda inclinação para a ausência de linguagem, o que é infinitamente mais do que uma incapacidade ou aversão de se comunicar" (BENJAMIN, 2009, 71).

Por fim, voltando-se para a infinidade de linguagens, não só dos homens, mas das coisas em geral, o nosso autor toca novamente no tema da tradução. É errôneo pensar que ele estivesse concebendo e atribuindo à linguagem decaída um caráter menor e que por isso devesse ser deixada de lado. Pelo contrário, com o estudo empreendido, podemos afirmar que Benjamin quisesse se fazer acrescentar aos estudos dos signos esta possibilidade abrangente, que remete à linguagem um percurso, desde a magia do nome à queda, e da queda à magia do julgamento. Estes três elementos estão presentes na obra de Benjamin.

Interessa-nos nos determos nestes elementos, pois eles são importantes para o estudo sobre a atividade da crítica enquanto escrita e leitura de mundo; enquanto crítica literária e crítica histórico-filosófica; e enquanto "destruição crítica e promessa de Redenção" (GAGNEBIN, 2013, 31)

\section{Os Pressupostos para uma Crítica}

De início, gostaríamos de nos deter um pouco na relação dentro e fora estabelecido por Benjamin, já desde o início do ensaio. Lá ele diz que as essências espiritual e linguística "vistas de fora", (von außen) não coincidem. Toda essa importante passagem, como já mencionamos acima, enfatiza o caráter imediato da linguagem, pois a única coisa que ela, a linguagem comunica, é a si mesma. Por isso não há um falante da linguagem ${ }^{7}$, e, por isso também, que a essência espiritual só coincide com a essência linguística na

7 “Es gibt also keinen Sprecher der Sprachen" BENJAMIN, 2016, posição 6563 Doutorando pelo PPGF - UFRJ. Brasileiro, residente no Rio de Janeiro-RJ. E-mail: brazil.filosofia@gmail.com 
medida em que é comunicável, pois a comunicabilidade da coisa é a própria linguagem. Em e não através: Das geistige Wesen teilt sich in einer Sprache und nicht durch eine Sprache mit. (BENJAMIN, 2016, posição 6573, grifo nosso)

Com esta concepção, Benjamin recusa que se conceba a linguagem como mediação. Por mediação, poderíamos entender, por exemplo, que nos aproximamos de uma coisa por meio ou através da linguagem. Benjamin está recusando, portanto, que a linguagem seja uma representação (Vorstellung) ${ }^{8}$.

Pouco mais adiante, Benjamin faz a seguinte afirmação: "precisamente porque nada se comunica através da língua, aquilo que se comunica na língua não pode ser limitado nem medido do exterior (von außen) $)^{9 "}$, e com isto Benjamin sela o sentido da linguagem como infinita, mágica e imediata. Novamente aqui, Benjamin aplica a mesma expressão usada lá em cima, que na edição brasileira aparece traduzida ora por "de fora" ora por "do exterior". E linhas abaixo, novamente a mesma relação dentro e fora: “(...) conhecemos outras linguagens que nomeiam as coisas? (...) O que não conhecemos fora da linguagem humana é uma linguagem nomeadora" (BENJAMIN, 2013, 54) ${ }^{10}$. Ou seja, se por um lado a linguagem nomeadora é a essência da linguagem humana, isto não supõe, em contra partida, que suponhamos um lado externo à linguagem. Para Benjamin,

8 O problema da representação nos conduz a uma importante oposição formulada por Walter Benjamin sobretudo a partir do livro sobre o Barroco. Trata-se da oposição entre Darstellung e Vorstellung, apresentação e representação, respectivamente. Acerca disto, conferir artigo de J. M.Gagnebin, "A palavra Darstellung - utilizada por Benjamin para caracterizar a escrita filosófica — não pode, (aliás, nem deve), ser traduzida por 'representação', como o faz Rouanet (que compreendeu perfeitamente o alcance do texto, conforme sua 'Apresentação' muito esclarecedora demonstra, mas que o traduziu, às vezes, de maneira pouco precisa), nem o verbo darstellen pode ser traduzido por 'representar'. Mesmo que essa tradução possa ser legítima em outro contexto, ela induz, no texto em questão, a contra-sensos, porque poderia levar à conclusão de que Benjamin se inscreve na linha da filosofia da representação - quando é exatamente desta, da filosofia da representação, no sentido clássico de representação mental de objetos exteriores ao sujeito, que Benjamin toma distância. Proponho, então, que se traduza Darstellung por 'apresentação' ou 'exposição', e darstellen por 'apresentar' ou 'expor', ressaltando a proximidade no campo semântico com as palavras Ausstellung (exposição de arte) ou também Darstellung, no contexto teatral (apresentação)". GAGNEBIN, Jeanne-Marie. Do conceito de Darstellung em Walter Benjamin ou verdade e beleza. Kriterion, Belo Horizonte, v.46, n.112, 183-190, Dec. 2005. Available from <http://www.scielo.br/scielo.php?script=sci arttext\&pid=S0100-512X2005000200004\&lng=en\&nrm=iso>. acesso 19 Nov. 2019. http://dx.doi.org/10.1590/S0100-512X2005000200004.

9 Denn gerade, weil durch die Sprache sich nichts mitteilt, kann, was in der Sprache sich mitteilt, nicht von außen beschränkt oder gemessen werden (BENJAMIN, 2016, posição 6580-6590)

10 Kennen wir aber noch andere Sprachen, welche die dinge benennen? (...)Nur keine benennende Sprache kennen wir außer der menschlichen (BENJAMIN, 2016, posição 6585-6595)

Doutorando pelo PPGF - UFRJ. Brasileiro, residente no Rio de Janeiro-RJ. E-mail: brazil.filosofia@gmail.com 
é até mesmo o oposto disto, a linguagem humana, na medida em que dá nome às coisas, se só assim pode proceder é porque há uma proximidade entre o nome e aquilo que se manifesta na coisa, sua linguagem muda.

Mas se a linguagem compreende uma totalidade, sendo impossível um ponto de partida desde sua exterioridade, por que Benjamin, no início do ensaio, havia dito que "vistas de fora" as duas essências não coincidem? Qual o caráter "de fora" naquela conjuntura? Ou não terá sido Benjamin apenas retórico, na medida em que queria ilustrar a diferença entre as duas essências?

Se reconhecermos que no momento em que define a linguagem humana Benjamin traça o caráter definitivo da linguagem, permitindo-o em seguida, e de modo conclusivo, a definir a essência espiritual como linguística, como ele diz na passagem a seguir: "Se a essência espiritual for idêntica à essência linguística, a coisa é, em sua essência espiritual, o meio [Medium] de comunicação, e aquilo que nela se comunica é - em função desse seu estatuto de meio - precisamente esse próprio meio (a linguagem)" (BENJAMIN, 2013, 57-58), na sequência a afirmação: "Assim, a linguagem é a essência espiritual das coisas 11", o que se deve pensar daquele caráter externo à linguagem mencionado anteriormente?

Em termos textuais, Benjamin abandona esta atribuição. Ele não volta a supor um ponto de vista exterior à linguagem. A partir de determinado momento, em vez da relação fora/dentro, o autor coloca o problema da queda (Sündenfall) da linguagem.

Outra observação pontual e que contradiz com o início do texto é que, também no mesmo trecho da citação acima, Benjamin atribui que é o homem o falante da linguagem. Lembremos: lá no início ele havia feito a afirmação Es gibt also keinen Sprecher der Sprachen, isto é, não há um falante da linguagem. E no trecho em que assevera a linguagem como nomeação, ele afirma weil er im Namen spricht, der Mensch der Sprecher der Sprache, o homem é o falante da linguagem, mas tão somente porque ele "fala no nome".

Sabemos, tal como vimos na primeira parte deste artigo, que a concepção benjaminiana de linguagem não parte da arbitrariedade dos signos:

11 Sprache ist dann das geistige Wesen der Dinge. BENJAMIN, 2016, posição 6626-6636 Doutorando pelo PPGF - UFRJ. Brasileiro, residente no Rio de Janeiro-RJ. E-mail: brazil.filosofia@gmail.com 
a linguagem não fornece jamais meros signos, Die Sprache gibt niemals bloße Zeichen -. Mas Benjamin é, de certa forma, ambíguo quanto a essencialidade dos signos, uma vez que se a relação, por um lado não é arbitrária, por outro não é essencial, "pois a coisa enquanto tal não tem palavra"12, e, por isso, Benjamin refuta também as refutações místicas às teorias burguesas. E é este ponto médio entre não arbitrariedade e não essencialidade que abre caminho para a teoria da tradução, onde se concebe a linguagem como tradução daquilo que não tem nome em nome ${ }^{13}$.

Neste ensaio, de 1916, Benjamin dá início a uma teoria da tradução que é completada com o ensaio escrito em 1921, Die Aufgabe des Übersetzers, A Tarefa do Tradutor. Mas, em ambas, não faz sentido falar em tradução entre línguas se não se menciona aqui um aspecto central da teoria da linguagem de Benjamin, que é a noção de queda. Seria a queda adâmica da perda do paraíso a perda original da nomeação das coisas mudas em palavras, e também o início da pluralidade entre as línguas. De tal modo que a tradução original dá lugar à tradução entre as múltiplas línguas, que por sua vez, não falam desde o nome da coisa. É a perda desta linguagem originária que dá início à arbitrariedade dos signos. Mais uma vez, assim como ocorre com o "falante da linguagem", que de início é refutado por Benjamin, e posteriormente assumido em sua teoria do nome, a arbitrariedade, que é negada na relação paradisíaca da linguagem, é aqui assumida, porém somente após a queda. É certo dizer que toda a filosofia de Benjamin, e não somente a sua filosofia da linguagem, guarda uma importante relação com este caráter intrínseco de uma perda originária.

Mas o que parece mais interessante é que a admissão de um "falante da linguagem" é condicionado pela formulação do lugar do homem e do nome nessa linguagem, algo que de início é desconhecido, enquanto a admissibilidade da arbitrariedade passa necessariamente pela questão da queda. A admissão de certos pressupostos são condicionados pelo momento em que o texto se encontra. Não há um falante da linguagem antes de reunir, textualmente, as duas

12 weil die Sache an sich kein Wort hat. BENJAMIN, 2016, posição 6714

13 (...) sie ist die Übersetzung des Namenlosen in den Namen. BENJAMIN, 2016, posição 6727 Doutorando pelo PPGF - UFRJ. Brasileiro, residente no Rio de Janeiro-RJ. E-mail: brazil.filosofia@gmail.com 
essências, espiritual e linguística, que de início não são coincidentes. A arbitrariedade da língua só é admitida a partir do momento em que se admite e se define a queda.

Dito isto, parece lícito podermos trocar a suposição de uma oposição dentro e fora da linguagem por uma oposição entre linguagem paradisíaca e linguagem decaída. O próprio percurso do texto nos permite assim concluir. Com isto, o "equivalente" "fora" seria trocado pelo "decaído", tendo em vista, no entanto, que a condição paradisíaca da linguagem vigora, pois não há um fora da linguagem, mas graus de essencialidades mais distantes, ou, talvez numa definição mais precisa, a queda seria a perda de qualquer essencialidade e a impossibilidade de sua retomada, que, paradoxalmente, permanece requerida. Acrescenta-se, contudo, a esta perda da essencialidade, um segundo e terceiro significados do pecado original: uma nova imediatidade - em lugar da magia do nome, a magia do julgamento; e o terceiro significado, a origem da abstração na linguagem. Haveria, com estas hipóteses, dois tipos de linguagem: a nomeadora, concreta, paradisíaca, mágica e imediata; e a judicante, "que não repousa mais feliz em si mesma":

Essa imediatidade na comunicação no abstrato instalou-se como judicante quando o homem, pela queda, abandonou a imediatidade na comunicação do concreto, isto é, o nome, e caiu no abismo do caráter mediado de toda comunicação, da palavra como meio, da palavra vã, no abismo da tagarelice (BENJAMIN, 2013, 69)

Haveremos de perguntar, portanto: qual é a linguagem usada por Benjamin em seu trabalho filosófico? Qual é a linguagem filosófica? Ela é a linguagem decaída a procurar pelo nome, ou é uma linguagem que compensa a perda enquanto tribunal? Ou não seriam estas perguntas um tanto quanto equivocadas em sua formulação?

É procurando trazer respostas a estes tipos de questões que os autores têm procurado interpretar e dar novas respostas acerca do opus benjaminiano.

Moses, em seu estudo sobre os dois ensaios sobre a linguagem, a que ele atribui ao paradigma teológico, dirá que estes "se completam perfeitamente" ao mesmo tempo em que "se enfrentam radicalmente" pela tendência que os move (MOSES, 1992, 86). Isto porque o primeiro ensaio, Sobre a Linguagem,

Doutorando pelo PPGF - UFRJ. Brasileiro, residente no Rio de Janeiro-RJ. E-mail: brazil.filosofia@gmail.com 
descreve um processo de decadência, enquanto A Tarefa do Tradutor descreve um processo de reassunção até sua realização utópica na "língua pura". $\mathrm{Na}$ soma de ambos os processos, Moses descreve a seguinte sequência: nascimento glorioso, pecado original e queda, seguida de um processo de purificação e marcha até a nova vida (MOSES, 1992, 87). O mesmo Moses interpreta a totalidade da obra de Benjamin contendo uma "unidade secreta" (MOSES, 1992, 81). Desde seus primeiros textos, Benjamin coloca frontalmente uma problemática em torno da escrita da história, em que a questão metodológica ("como conhecer a história?") implica uma opção de ordem metafísica: que tipo de história queremos definir? (MOSES, 1992, 85).

Desta forma, a partir da "unidade" da obra de Benjamin, o que é cronologicamente último (as Teses sobre o Conceito de História14) é desde sempre o primeiro ao longo de suas reflexões, convindo ao estudioso de seus trabalhos observar as diacronias e sincronias das diversas fases. Moses separa a obra de Benjamin em três fases e atribui a cada uma delas um paradigma. 1.0 paradigma teológico, marcado sobretudo pelos seus dois ensaios, estudados por nós nas linhas acima; 2. o paradigma estético, marcado sobretudo pelo livro sobre o Drama Barroco Alemão; 3.o paradigma político, a partir de 1925, sobretudo, que dentre os muitos componentes, certamente o mais importante é a descoberta do marxismo. Moses atribui ao paradigma teológico uma "estabilidade maior", pois, manifesto de forma primeira, e, posteriormente, de maneira "mais ou menos oculta", esteve sempre presente "ao longo de toda a sua evolução". Ao paradigma político, Moses atribui maior completude, "na medida em que nele se combinam todos os elementos de sua visão de história". Ao paradigma estético, Moses atribui maior centralidade, sobretudo porque ela desempenha uma espécie de mediação entre o teológico e o político.

Gagnebin, por sua vez, trabalha a partir de uma indistinção, de um limiar, para utilizar um termo utilizado por ela, entre a literatura e a história, por isso ela nos diz:

14 BENJAMIN, Walter. Sobre o Conceito de História in Obras Escolhidas: Magia e Técnica, Arte e Política. Tradução de Sérgio Paulo Rouanet. Editora Brasiliense, 1994. 
Convicção também que literatura e história (Historie) andam juntas sem que isso signifique, necessariamente um relativismo resignado da "ciência histórica" ou um realismo militante da literatura. Convicção, enfim, que me parece partilhada por Benjamin e me permite estabelecer uma ligação entre sua filosofia da história e sua teoria da literatura" (GAGNEBIN, 2013, 2-3)

Ela atribui à obra de Benjamin outro "núcleo central", que é definido como a "produtividade da perda e da morte, seja na história ou na linguagem" (GAGNEBIN, 2013, 5). Em torno deste núcleo central, que permite a ela uma indistinção de princípio entre filosofia da história e teoria da literatura, gravitam quatro conceitos importantes na obra de nosso autor: a alegoria (Alegorie), a Origem (Ursprung), a Tradução (Übersetzung) e a Crítica (Kritik).

O que Gagnebin, Moses, dentre outros autores estudiosos da obra de Benjamin procuram fazer, é analisar e observar no todo da obra de Benjamin o lugar que a primordial filosofia da linguagem ocupa, tendo-se em conta as continuidades e descontinuidades do pensamento do autor berlinense. O que Benjamin carrega desta análise exegética do Gênesis para seus textos posteriores? E especificamente para a noção de crítica? Que pressupostos o ensaio estudado por nós carrega e que podem ser expostos ante uma possível concepção da ideia de Kritik? Vimos com Gagnebin que a Kritik tem seu lugar entre outros três conceitos benjaminianos.

Com tudo o que foi exposto, resta-nos indagar sobre a possibilidade de extrairmos alguns pressupostos da filosofia da linguagem na noção de crítica. Algumas considerações parecem vislumbrar a proposta.

a) Ausência de fronteiras que separem a literatura da filosofia.

De fato não há para o autor nascido em Berlim uma preocupação em estabelecer um pensamento puro, uma intuição intelectual, em que se delimitasse o trabalho do filósofo. Com isto, ante a pergunta "o que significa pensar?", nosso autor traria como resposta algo bastante diverso: a compreensão do mundo como escrita, o conceito de escritura. Selligman-Silva em seu Ler o Livro do Mundo (1999) procura demonstrar como a influência dos românticos de lena exercem sobre nosso autor nesta visão de mundo e que também é partilhada pela concepção de linguagem não instrumental. Para os românticos "mundo e linguagem se misturam como as cartas de um baralho"

\footnotetext{
Doutorando pelo PPGF - UFRJ. Brasileiro, residente no Rio de Janeiro-RJ. E-mail:
} brazil.filosofia@gmail.com 
(SELLIGMAN-SILVA, 1999, 29), e por isso: "O conceito de escritura serve tanto de anteparo crítico com relação às teorias representacionistas do conhecimento, como também exige a articulação do 'saber' a partir de uma nova visão da História e do passado" (SELLIGMAN-SILVA, 1999, 16-17). Portanto, não apenas mundo como escritura, mas também a história é concebida por Benjamin como um texto. $E$ assim procede Benjamin, no trabalho do estudioso que lê mundo e história como escrita, e a escrita como mundo e história.: "Essa leitura do que nunca foi escrito é a realização da crítica como atualização, como médium-dereflexão, na qual o texto nasce da leitura (SELLIGMAN-SILVA, 1999, 220).

Uma vez não concebida como filosofia pura, o trabalho benjaminiano se divide, ora em crítica literária, ora em crítica histórico-filosófica: "O que tornava as críticas de Benjamin distintas das demais era justamente esta mescla presente nelas entre 'crítica literária' (mas também 'teoria da literatura') e filosofia" (SELLIGMAN-SILVA, 1999, 174). Mas seria enganoso acreditar que nosso autor não estivesse envolvido com a justificação desta não fronteira entre o literário e o filosófico. Há, de fato, uma concepção acaba de arte e verdade, que não nos cabe aqui nos determos, que indiretamente se desdobra nas críticas benjaminianas. Não à toa afirma o autor em seu ensaio Goethes Wahlverwandtschaften: "todas as obras autênticas têm seus irmãos no âmbito da filosofia" (BENJAMIN, 2018), e pouco mais adiante completa: "Pois o que a crítica demonstra por fim na obra de arte é a possibilidade virtual de formular o seu teor de verdade como sendo o mais elevado problema filosófico" (BENJAMIN, 2018, 81) $)^{15}$.

O pressuposto gnosiológico benjaminiano para tratar das questões da verdade é a de que o conhecimento humano não encontra ela. A verdade é de ordem teológica. Há, portanto, uma distinção entre conhecimento e verdade: "Benjamin estabelece uma distinção entre conhecimento (obra da ciência,

15 Cláudia Castro em seu "AAlquimia da Crítica" relata esta questão da verdade, que em Benjamin, segundo ela, opera como fator de cisão entre seu pensamento e o dos românticos, sobretudo quanto ao conceito de Kritik.

Doutorando pelo PPGF - UFRJ. Brasileiro, residente no Rio de Janeiro-RJ. E-mail: brazil.filosofia@gmail.com 
assunto de método) e verdade, o que se apreende, mas não por demonstração." (MATTOS, 1999b, 11).

b) A Kritik opera a partir da perda originária da linguagem

No ensaio sobre a linguagem, vimos que há duas linguagens: a adâmica e essencial, e a decaída e inessencial, cujo traço mais notado por Benjamin é a de ser uma linguagem judicante, ou seja, uma linguagem que emite juízos, que julga. Além disto, a linguagem humana encontra, em ambas as dimensões apresentadas, dois aspectos. De um lado ela é "significativa" (WITTE, 2017), ela nomeia algo; e, por outro, ela "exprime a essência espiritual do falante". Witte nos diz que a linguagem contemporânea participa da linguagem adâmica no nome, por isso a crítica deve investir-se neste caminho, afinal o nome é a "totalidade intensiva da língua" (intensiven Totalität der Sprache): "Benjamin concebe a tarefa da crítica como tradução na linguagem adâmica, que é mais perfeita, ou como ativação daquilo que na língua é símbolo do não comunicável" (WITTE, 2017, 33). Esta tarefa de assunção a uma língua mais perfeita e próxima da adâmica seria solvida pela tradução, e é este encaminhamento que o texto Aufgabe des Übersetzers realiza. Tal ativação mencionada por Witte se mostra na extrema proximidade entre história e religião, ou, digamos, numa formulação mais conceitual, no caráter messiânico da história. Como proceder no entendimento acerca deste caráter messiânico se torna então questão de interpretação da obra do autor.

O lugar e o caráter da perda é debate central acerca da obra benjaminiana. Gagnebin, em texto sobre a alegoria, nos conta um pouco sobre a história da perda do sentido imediato ${ }^{16}$ das obras clássicas relidas pelos

16 Para uma melhor apreciação dos conceitos de imediato e mediação, Cf. ABBAGNANO, N. Dicionário de Filosofia. Lá, ambos os conceitos são aludidos a partir de alguns autores da história da filosofia, particularmente Hegel. No entanto, insuficiente para compreendermos a discussão no âmbito da filosofia de Benjamin, afinal Benjamin traz nova problemática ao assunto. Por um lado, poderíamos dizer que o lugar desta perda, que discutimos acima, pode ser concebido como perda do imediato do significado. Mas, segundo o próprio conceito, poderíamos entender que Benjamin é ambíguo quanto àquilo que é imediato, pois ainda que a alegoria, cuja distância entre significante e significado se faz na oposição ao símbolo, seja pressentida esta perda da imediaticidade, Benjamin a supõe em lugar dela o puro meio, que manifesta tanto a violência mítica, no exemplo textual da cólera, quanto a violência divina, redentora, que aniquilará o direito. A questão toda passa então a ser: qual a relação entre puro meio e imediato. Em Doutorando pelo PPGF - UFRJ. Brasileiro, residente no Rio de Janeiro-RJ. E-mail: 
epigonais séculos depois, e que nos interessa aqui. Nestas releituras, a relação direta entre nome e coisa se perdeu porque a língua mudou, o mundo mudou e a obra aparentemente não diz o que ela parecia querer dizer. Os leitores gregos de séculos posteriores a Homero tinham dificuldade de entender o sentido das palavras, porque seu uso corrente havia se transformado, não era mais o mesmo. Esta leitura de Gagnebin se presta a interpretar um daqueles quatro elementos que citamos acima, a alegoria, mas ela serve para elucidar também a crítica, na medida em que têm em comum o núcleo da perda. Conceitualmente, a alegoria se opõe ao símbolo. Em que a alegoria e o símbolo se opõem e qual a importância da concepção de alegoria para Benjamin?

Alegoria e símbolo divergem quanto ao sentido imediato que eles denotam. Ou, dito de outro modo, a alegoria é destituída de significação imediata, coisa que é própria do símbolo. Por isto, a alegoria sempre foi preterida ante o poder do símbolo, pois este contém em sua imediaticidade a própria coisa, enquanto aquele só pode significar algo a partir da perda ou da ausência do algo. $E$, embora os dois ensaios sobre a linguagem não façam menção a estes dois conceitos, é bastante tangível a relação direta que se pode fazer entre símbolo e linguagem adâmica e alegoria e linguagem decaída.

É nesta direção que define Todorov, citado por Gagnebin: "O símbolo é, a alegoria significa". (TODOROV apud GAGNEBIN, 2013, 34) Esta expressão, de cunho ontológico, sugere a imediaticidade do símbolo e remete ao problema e os diversos caminhos encontrados pelos filósofos na busca pelo ser ${ }^{17}$.

Prosseguindo a citação de Todorov. Ele havia dito que "o símbolo é, a alegoria significa". Na sequência ele diz o seguinte: "o primeiro faz fundir-se significante e significado, a segundo os separa (TODOROV apud GAGNEBIN, 2013 , 34). Ora, no símbolo a referida fusão significante/significado no fundo quer

ambas é inatribuível qualquer mediação. Ao puro meio concebido por Benjamin podemos conceber uma nova imediaticidade? O que quer Benjamin com as manifestações de puro meio?

17 Não é arbitrário que Platão, no diálogo Crátilo, tenha relacionado a palavra para o nome, em grego Onoma, com o ser, On: "Quer parecer-me que o vocábulo ónoma (nome) é uma proposição concentrada, que afirma a existência do ser (on) que investigamos. Compreenderás mais facilmente isso mesmo naquilo que chamamos onomastón (a ser denominado), pois diz claramente que se trata do ser sobre que investigamos (on hou másma estin) (Crátilo, 421b)

Doutorando pelo PPGF - UFRJ. Brasileiro, residente no Rio de Janeiro-RJ. E-mail: brazil.filosofia@gmail.com 
dizer que não existe essa relação, pois o que permite falar do significante é o significado e vice-versa. Se ambos estão fundidos junto a um algo e esse algo não requer nenhuma mediação, não há porque mencionar uma relação significante/significado. De tal maneira que só faz sentido falar em ambos na alegoria.

Toda uma longa literatura que remonta, sobretudo, aos românticos, inscreve no símbolo um elemento primordial e hierarquicamente superior. Essa predileção da filosofia e da poesia com relação ao imediato remete também a uma recusa desses ao caráter temporal e, por isso: "Na tradição filosófica clássica, a alegoria sempre foi depreciada pela sua historicidade e pela sua arbitrariedade" (GAGNEBIN, 2013, 31). Por outro lado, o caráter temporal do símbolo surge apenas para valorizar o eterno e o instantâneo:

O símbolo é, ao mesmo tempo, instantâneo e eterno nesta instantaneidade, enquanto a alegoria - pensemos por exemplo na Melancolia de Dürer continua tributária de um desenvolvimento no tempo que afeta tanto sua construção quanto sua compreensão e acarreta seu envelhecimento histórico. (GAGNEBIN, 2013, 35)

Daí uma importante afirmação de Benjamin citado pela autora logo após a passagem destacada, que aprofunda a distinção entre símbolo e alegoria. $\mathrm{O}$ símbolo não se concebe separado da coisa, é a junção total da ideia e da coisa; enquanto a alegoria só pode ser alegoria na medida em que representa algo distinto a si próprio.

O estudo de Gagnebin descreve o uso e a importância da alegoria ao longo do processo histórico. É interessante destacarmos que a descrição da alegoria inserida no processo histórico aponta para o próprio processo que a constitui e torna possível. A alegoria, que vige na separação entre significante e significado, é oriunda da distância, da separação e da transformação inerentes ao processo, e por isto ele contém, ele carrega historicidade.

Embora valorizada negativamente pelos românticos, a alegoria conta a sua própria história a partir da transformação dos significados das palavras no mundo antigo, que a tornou incipiente e causou o estranhamento de alguns diante da leitura de Homero. A alegoria nasce da interpretação do texto: 
a interpretação alegórica nasce da distância histórica que separa os leitores do texto literal. Os gregos posteriores a Homero, por exemplo, se conseguem entender as palavras da epopeia, não podem mais, porém, admitir seu sentido. A interpretação alegórica nasce do escândalo que representa o texto literal para a razão filosófica que se estabelece, em Xenófanes como em Platão, como juiz da verdade da poesia. (GAGNEBIN, 2013, 32)

Surge nesse contexto a distância entre leitura e obra, entre a leitura e a escrita: Não é Homero que se engana, mas uma leitura ingênua, imediata, do texto homérico.

O sentido literal não é o sentido verdadeiro. Deve-se aprender uma outra leitura que busque sob as palavras do discurso seu verdadeiro pensamento, uma prática que os estoicos chamam de hyponoia (subpensamento) e à qual Filo de Alexandria dará seu nome definitivo de alegoria (de alio, outro, e agorein, dizer). (GAGNEBIN, 2013, 32)

$\mathrm{Na}$ tradição cristã, a exegese se desenvolve. Começa-se a definir tipos de leitores. Sabemos porque é importante a leitura no cristianismo, e, por isso, porque é importante a exegese textual: as palavras de Deus somente são acessíveis pelas sagradas escrituras. Gagnebin, contudo, salienta um aspecto contundente da leitura cristã: a interpretação do antigo testamento, e não apenas as palavras dos profetas, da chegada do messias: "desde os inícios do cristianismo, o Antigo Testamento aparece como um discurso premonitório do Novo, do advento messiânico" (GAGNEBIN, 2013, 32). Central na interpretação da história, a "Alegoria ocupa, portanto, um lugar privilegiado na religião cristã: ela não é somente uma forma de interpretação, ela determina a compreensão da História da Salvação" (GAGNEBIN, 2013, 33).

No cristianismo, contudo, a hierarquia de leitores, estabelecido ainda na Antiguidade, produz a forma hierárquica da interpretação, centralizando nas figuras eclesiásticas a determinação da correta leitura: "há aqueles que conhecem a verdadeira leitura, aqueles que foram iniciados ao verdadeiro sentido e que deverão, portanto, guiar e dirigir os que não conhecem, os que ficam no sentido literal, ou então moral da escritura" (GAGNEBIN, 2013, 33). Daí o "protesto luterano" que duplamente luta contra as hierarquias católicas: 1. a hierarquia eclesial, do poder dos padres e dos bispos, em suma, do clero em sua organização e poder; 2. e a "hierarquia dogmática" que diz respeito à interpretação das sagradas escritas (GAGNEBIN, 2013, 33).

Doutorando pelo PPGF - UFRJ. Brasileiro, residente no Rio de Janeiro-RJ. E-mail: brazil.filosofia@gmail.com 
Soa paradoxal que o luteranismo tenha protestado contra o intermédio da igreja com relação à fé do crente, propondo uma relação imediata deste com Deus, pois "o crente não precisará mais passar pela palavra mediadora do sacerdote para chegar à Palavra de Deus" (GAGNEBIN, 2013, 33), mas ao mesmo tempo tenha contribuído para desenvolver e ampliar os meios que se desdobram a partir da distância com o dogma, sendo responsável até mesmo pelo desenvolvimento da crítica ${ }^{18}$.

Como salienta Gagnebin, a partir do Renascimento, e, portanto, após a Reforma, ocorre uma volta ao texto, o que "desloca a interpretação alegórica de seu lugar primeiro" (GAGNEBIN, 2013, 33). Afastada do dogma, a

\begin{abstract}
interpretação alegórica não oferece nenhum fundamento seguro: nascida da necessidade de conciliar o teor do texto canônico com as exigências da razão e da moral, a interpretação alegórica pode mesmo construir uma ligação entre o sentido e a imagem; mas ela se mostra incapaz de estabelecer a necessidade desta ligação (GAGNEBIN, 2013, 33)
\end{abstract}

A necessidade de conciliar o texto canônico com as demandas racionais e morais não ocupa, no entanto, o hiato entre significante e significado. Por isso, padece a alegoria de estabelecer o fundamento dessa necessidade: "É nesta arbitrariedade da relação significante-significado que vai esbarrar a crítica moderna da alegoria, uma arbitrariedade que tem seu fundamento no hiato entre sagrado e profano" (GAGNEBIN, 2013, 33).

Tal estado de situação perfaz o paradigma moderno. Dele resulta a posição do romantismo alemão, que num gesto de recusa da modernidade valoriza a "feliz evidência do sentido", a "espontaneidade do gênio", em suma, a imediatidade do símbolo. Se conjugarmos esta noção de alegoria e símbolo com o que havíamos visto sobre a linguagem, parece clara a interconexão entre ambas: elas remetem a uma perda do sentido imediato e intrínseco à própria coisa. E ainda mais que isso: Benjamin parece, no bojo dos questionamentos

$18 \mathrm{Em}$ "O que é a Crítica?", M. Foucault avalia o lugar e o surgimento da atitude crítica no bojo do mundo cristão, a partir de um processo de laicização da vida, a qual vai desaguar num modo de vida civil que corresponde a arte de "não ser de tal forma governado". Cf. FOUCAULT, M. Qu'est-ce que la critique? Critique et Aufklärung. Bulletin de la Société française de philosophie, Vol. 82, n 2, 35 - 63, avr/juin 1990 (Conferência proferida em 27 de maio de 1978). Tradução de Gabriela Lafetá Borges e revisão de Wanderson Flor do Nascimento.

Doutorando pelo PPGF - UFRJ. Brasileiro, residente no Rio de Janeiro-RJ. E-mail: brazil.filosofia@gmail.com 
acerca da modernidade, em vez de partir da recusa desta perda, procurando valorizar o simbólico, o imediato, se engajar e encampar uma filosofia capaz de ler essa perda mesma, fazendo dela o tema central de sua filosofia. Isto fica claro em dois textos seus, contemporâneos um ao outro: o Goethes Wahlverwandtschaften, onde afirma que a crítica é "mortificação das obras", e em Zur Kritik der Gewalt, em que vislumbra-se a "destruição do direito". No interior de ambas as críticas, remanesce um fundo religioso, seja a esperança, no caso do primeiro texto, e a redenção messiânica, no caso do segundo.

c) A Kritik não é um tribunal?

Se a crítica fala desde a perda, se seu traço central é a melancolia, sua vocação é fazer eco a esta perda, em vez de valorizar-se como linguagem que julga sobre as coisas? Não concebida propriamente como linguagem judicante, a crítica evita compensar a perda originária? Qual seria esta concepção benjaminiana de crítica respaldada na relação de linguagem decaída? Seria possível ao crítico escolher por uma das duas linguagens, investindo na linguagem nomeadora, ainda que perdida, ante a tagarelice da linguagem judicante? Neste artigo, não ofereceremos a resposta a estas questões.

Embora devamos admitir que a Crítica faz frente ao mito relação de oposição, por outro lado, por um encaminhamento característico de Verdade e de experiência, esta mesma crítica, desviando-se do caminho da Aufklärung, termina por mostrar que a racionalidade moderna não emancipou-se do mito, fazendo-o repetir-se. Como diz Ernani Chaves em um artigo sobre a crítica da violência, Benjamin "começa a escrever a dialética do esclarecimento". (CHAVES, 1994)

De certo modo, também ela, a Kritik, foi antevista no ensaio sobre a linguagem. Citamos acima que a linguagem que julga é paródia da linguagem criadora. E tal qual a nomeação, em seu duplo aspecto, revela a essencialidade das coisas e daquele "falante da linguagem", a linguagem judicante faz recair 
sobre aquele que pergunta o julgamento mesmo: "Essa monstruosa ironia é o sinal distintivo da origem mítica do direito ${ }^{19 "}$ (BENJAMIN, 2009, 69, grifo nosso).

Prosseguindo em nossas observações, é necessário afirmar que a Crítica é subscrita na ordem que distingue a vida justa da mera vida. A mera vida é dominada pela culpabilidade, e onde há culpabilidade, aí reina o mito. O ensaio Zur Kritik der Gewalt, ao fazer a crítica da violência adota como procedimento buscar manifestações de violência pura, sem mediações. Razão disto é a crítica inerente ao direito, que, tal como a linguagem decaída, instrumentaliza, não a linguagem mas a violência. Tanto o direito natural quanto o direito positivo a instrumentaliza. Percebemos uma interconexão clara entre a linguagem e a violência. Que conexão é esta? Para ser possível responder a esta questão, teríamos de entender a distinção que Benjamin neste ensaio estabelece entre o mítico e o divino. E o que se encontra é uma Gewalt mítica, sem mediação e sem justificação. E para depor o direito com seu uso instrumental da violência, convoca-se uma violência divina. Somente a violência divina redimiria a vida culpada, pois na violência mítica vige um poder pelo poder, uma violência por pura violência. A simples vida é o campo de ação desta Gewalt, e, por isso, a culpa é inerente a ela. Mas a herança religiosa da linguagem faz o requerimento de uma instância salvadora, a redenção messiânica. Com isso podemos afirmar que a crítica se concebe, por um lado como destruição, mas ela traz inerentemente a marca inegável da redenção, a melancolia do paraíso. Como quer que se conceba esta melancolia na obra de Benjamin, deve-se enfatizar aquilo que fora dito por Gagnebin, que prefere pensar não um autor "parado" na melancolia, mas que a concebe como algo produtivo. O hiato alegórico entre significante e significado, a historicidade própria da significação, compõem junto à crítica. Nela se mostra a força produtiva, o novo, portanto, o alegórico, a crítica é mortificação, pois

(...) na ética benjaminiana, sustentar o caráter radical da morte é conservar a diferença entre a vida e a vida justa, mantendo firme esta distinção. É ela, a

19 Diese ungeheure Ironie ist das Kennzeichen des mytischen Ursprungs des Rechts. BENJAMIN, 2016, posição 6778.

Doutorando pelo PPGF - UFRJ. Brasileiro, residente no Rio de Janeiro-RJ. E-mail: brazil.filosofia@gmail.com 
distinção, que abre o espaço que permite ao moderno a verdadeira experiência da história: a simultânea constatação do retorno do mito e do desejo de justiça, de redenção. Neste sentido, qualquer filosofia que pretenda, de algum modo, subtrair a radicalidade da morte está condenada à constante ressurreição do passado morto, podendo sempre ser apropriada pela ideologia dos vencedores, tão desprezada por Benjamin. (CASTRO, 2011, 120-121)

Doutorando pelo PPGF - UFRJ. Brasileiro, residente no Rio de Janeiro-RJ. E-mail: brazil.filosofia@gmail.com 


\section{REFERÊNCIAS}

AGAMBEN, G. Infância e História: destruição da experiência e origem da história. Tradução de Henrique Burigo. Belo Horizonte: EdUFMG, 2008.

BENJAMIN, Walter. Gesammelte Werke (German Edition). Braunschweig: Ideenbrücke Verlag, 2016

. As "Afinidades Eletivas" de Goethe in Ensaios reunidos: escritos sobre Goethe. Tradução de Mônica Krausz Bornebusch, Irene Aron e Sidney Camargo. São Paulo: Duas Cidades, ed.24, 2018

. Escritos sobre Mito e Linguagem (1915-1921). Organização, apresentação e notas de Jeanne Marie Gagnebin. Tradução de Susana Kampff Lages e Ernane Chaves. São Paulo: Duas Cidades: ed.34, 2013 (Coleção Espírito Crítico)

. Origem do Drama trágico alemão. Tradução de João Barrento. Belo Horizonte: Autêntica Editora, 2016.

CAMPOS, Haroldo de. A Arte no Horizonte do Provável e outros ensaios. São Paulo: Perspectiva, 1969.

CASTRO, Claudia. A Alquimia da Crítica: Benjamin e As Afinidades Eletivas de Goethe. Rio de Janeiro: Paz e Terra, 2011.

CHAVES, Ernani. MITO E POLÍTICA: NOTAS SOBRE 0 CONCEITO DE DESTINO NO "JOVEM" BENJAMIN. Trans/form/ação, São Paulo, n. 17, p.1530, 1994.

GAGNEBIN, Jean Marie. Lembrar Escrever Esquecer. São Paulo: editora 34, 2009.

. Limiar, Aura e Rememoração: ensaios sobre Walter Benjamin. São Paulo: editora 34, 2014.

. História e Narração em Walter Benjamin. São Paulo: editora Perspectiva, 2013 (coleção Estudos).

. Comentário filológico e crítica materialista. Trans/form/ação, [s.I.], v.

34, n. 2, p.137-154, 2011. FapUNIFESP (SciELO).

http://dx.doi.org/10.1590/s0101-31732011000400009.

FRAGOSO, Williard Scorpion P.. NOTAS SOBRE A VERDADE, O BELO, O BEM E A LINGUAGEM NO JOVEM BENJAMIN. Cadernos Walter Benjamin, Fortaleza, p.88-103, jan. 2011. Semestral. Disponível em:

<http://gewebe.com.br/pdf/cad06/texto_06.pdf>. Acesso em: 31 mar. 2019.

Doutorando pelo PPGF - UFRJ. Brasileiro, residente no Rio de Janeiro-RJ. E-mail: brazil.filosofia@gmail.com 
GALVÃO JUNIOR, João C. João C. Galvão Jr.: João C. Galvão Jr.. Cadernos Walter Benjamin, Fortaleza, v. 6, p.38-56, jan. 2011. Semestral. Disponível em: $<$ http://www.gewebe.com.br/pdf/cad06/texto_03.pdf>. Acesso em: 31 mar. 2019.

HEIDEGGER, Martin. A Caminho da Linguagem. Tradução de Márcia Sá Cavalcante Schuback. Petrópolis: Vozes, 2008.

LAGES, Suzana Kampff. Walter Benjamin: Tradução e Melancolia. São Paulo: editora da Universidade de São Paulo, 2019.

MOSES, Stéphane. El ángel de la historia: Rosenzweig, Benjamin, Scholem. Tradução para o espanhol de Alícia Martorelli. Madrid: Frónesis Cátedra Universitat de Valencia, 1997.

MEDEIROS, Mateus Gonçalves de. Mateus Gonçalves de Medeiros. Cadernos Walter Benjamin, Fortaleza, v. 4, p.15-37, jan. 2010. Semestral. Disponível em: <http://gewebe.com.br/cadernos_vol04.htm>. Acesso em: 31 mar. 2019.

PLATÃO. Teeteto e Crátilo. Tradução de Carlos Alberto Nunes. Belém: Universidade Federal do Pará, 1988.

SELIGMANN-SILVA, Márcio. Ler o Livro do Mundo. São Paulo: editora lluminuras, 1999.

WITTE, Bernd. Walter Benjamin: uma biografia. Tradução de Romero Freitas. Belo Horizonte: Autêntica Editora, 2017. 